\title{
土建工程项目的施工进度管理与控制综述
}

赵松涛

沈阳全运村建设有限公司

DOI:10.18686/bd.v2i4.1321

[摘 要] 由于土建工程涉及范围广, 所需要管理的内容多, 而面对众多的管理内容, 就会使建筑企业忽略对土建工程的进度 管理工作, 导致土建工程施工进度被延长。因此, 土建工程需要加强进度管理工作, 本文就对土建工程项目施工进度管理的重 要意义进行阐述,并提出做好进度管理工作的对策, 以期为土建工程管理工作提供参考依据。

[关键词] 土建工程项目;施工进度; 管理方法; 质量控制

在人们生活水平不断提高的背景下, 对建筑物的需求 量逐渐增加,在此种情况下,各种各样的土建工程应运而生, 使得土建工程行业成为我国国民经济的重要组成部分 [1]。但 是土建工程在施工过程中进度管理工作还存在一些问题, 对建筑企业的发展产生一定的负面影响。基于此,本文就对 土建工程项目的施工进度管理与控制进行探究, 以期推动 土建行业实现快速发展。

\section{1 土建工程项目施工进度管理的重要意义分析}

在我国土建工程行业快速发展的背景下, 使得土建工 程数量增多、规模变大、管理内容呈现出多样化趋势,包含 着建筑项目工程施工计划、施工材料、施工进度管理等方方 面面内容, 但是在这众多管理内容中, 进度管理最为重要, 不 仅关系到土建工程施工质量, 还关系到土建工程施工成本 和建筑企业的经济效益, 因此, 相关人员需要做好土建工程 管理中的进度管理工作,推动土建工程实现快速发展 ${ }^{[2]}$ 。通 常情况下, 土建工程项目施工进度管理的重要意义体现在 以下几个方面:

1.1 土建工程在开工前期,企业双方在合同中对建筑施 工工期有了明确的要求, 要求施工单位需要在规定的时间 内完工, 所以对土建工程进行进度管理可以将施工中遇到 的突发事件进行及时调整,进而保证土建工程如期完工。

1.2 由于我国土建工程具有复杂性特点,各个方面都需 要花费大量资金, 施工成本高,一旦工期延长, 就会增加不必 要的人力、财力等投人,在此种情况下, 就会导致土建工程成 本上升, 而对土建工程施工进度进行管理,可以保证保证施 工人员施工质量,降低工程施工中出现差错的几率,对所花 费的资金进行控制,保证工程资金使用合理,实现土建工程 成本控制工作 ${ }^{[3]}$ 。

1.3 土建工程工期长,在施工过程中经常会经历多个季 节,造成工程出现变更情况,影响土建工程工期。在此种情况 下, 相关人员对土建工程施工进度进行管理可以保证土建 工程如期完工, 进而帮助施工单位营造一个良好的形象, 吸 引更多建筑企业与其进行合作, 从而为施工单位获取更多 的项目,提升施工单位的经济效益。

1.4 相关人员在土建工程管理中实施进度管理工作可
以保证土建工程规模, 相关人员根据土建工程项目具体情 况制定科学合理的进度管理方法, 对土建工程项目施工进 度进行控制,进而保证土建工程项目施工质量,推动我国土 建工程行业实现快速发展。

\section{2 影响土建工程项目施工进度的主要因素分析}

2.1 人力.物力对土建工程项目施工进度的影响

任何项目在施工前期都离不开人力、物力以及财力, 只 有人力、物力、财力这三方面都得到了保证,才可以保证土 建工程项目施工进度 ${ }^{[4]}$ 。通常情况下, 人力、物力、财力对土 建工程项目施工进度的影响体现在以下两个方面:一方面, 一旦土建工程施工中缺乏人力, 就会出现无人施工的情况, 土建工程无法正常展开施工。另一方面,如果土建工程中缺 少财力, 就会造成施工材料、施工设备无法购买,施工材料使 用情况无法得到保证,降低土建工程施工效率。

2.2 施工技术对土建工程项目施工进度的影响

施工技术是土建工程项目施工中的一个重要支柱, 如 果施工技术落后,土建工程施工效率下降, 导致土建工程项 目施工进度延长,制约土建工程行业的快速发展 ${ }^{[5]}$ 。与此同 时, 土建工程项目在施工过程中经常会遇到一些突发情况, 出现工程变更情况,此种情况下,如果土建工程施工技术不 成熟, 就会导致工程变更情况无法及时处理,降低土建工程 项目施工效率,对土建工程项目产生严重的负面影响。

2.3 管理层对土建工程项目施工进度的影响

由于土建工程规模大, 在施工过程中如果缺少管理工 作, 就会导致部分环节施工进度延长, 增加土建工程施工难 度。通常情况下,管理层对土建工程项目施工进度的影响主 要体现在以下两个方面:一方面,如果管理人员缺少土建工 程项目管理经验和管理知识, 在土建工程项目展开施工过 程中就会出现管理层经验欠缺, 影响土建工程管理效率, 延 长土建工程施工时间。另一方面,由于管理层缺少管理经验, 就会造成土建工程施工资金受到影响, 降低土建工程经济 效益,制约土建工程行业的快速发展。

2.4 施工环境对土建工程项目施工进度的影响

不同地区气候、地形都存在一定差异性,此种情况下,施 工环境就会呈现出一些差异性, 一旦施工人员对施工环境 
不了解,在此种情况下,就会出现手忙脚乱的情况,增加土建 工程施工时间,与此同时,恶劣的天气,还会对土建工程施工 人员产生严重的人身安全, 对土建工程行业发展产生严重 负面影响。

\section{3 土建工程项目的施工进度管理与控制的对策}

3.1 加强人力、物力、财力的管理和控制工作

土建工程负责人需要在施工前期对土建工程施工中所 涉及的人力、物力等方面内容进行合理安排,对每一工作人 员的工作内容进行明确,结合具体的施工原则,建立完善的 目标责任制,将管理工作落实到每一位工作人员身上,调动 施工人员工作积极性,保证土建工程的工期控制效率[6 与 此同时, 土建工程负责人还需要加强土建工程预算造价审 计工作,培养工程预算工作人员的专业素质和能力, 保证工 作人员的专业知识储备量, 让其能够充分胜任此项工作, 保 证土建工程预算造价审计工作质量, 降低财力对土建工程 项目施工进度的影响。

3.2 注重土建工程项目进度控制的关键点

相关负责人要想保证土建工程项目施工进度, 就需要 注重土建工程项目进度关键点的控制工作, 具体可以从以 下几个方面展开:第一,相关人员需要根据土建工程具体情 况，制定完善的土建工程项目进程整体目标和进程规划，做 到对土建工程项目进程合理掌控[]。第二,相关人员在进行 土建工程规划工作时, 需要注重部分工作与整体工作的统 一协调性,如果出现进度不一致情况, 及时调整施工进度, 保 证土建工程施工进度合理。第三,土建工程项目在施工过程 中经常会涉及众多部门,针对此种情况, 就需要加强土建工 程项目多个部门的协调合作,不同部门及时进行沟通,从而 保证土建工程施工进度合理,推动土建工程行业快速发展。

3.3 规范土建工程项目施工工序

施工工序直接影响到土建工程施工进度, 一旦施工工 序不正确,就会导致土建工程施工进度受到影响。针对此种 情况, 相关人员就需要加强土建工程施工工序的规范工作, 具体如下: 一方面,土建工程项目施工单位需要在施工前对 土建工程施工工序进行查看, 对施工中每一阶段进行的时
间进行合理安排,根据土建工程项目施工具体情况,对施工 进度管理方案进行调整,提高土建工程施工进度管理质量。 另一方面,由于土建工程规模大, 在施工中所涉及到的生产 要素多,一旦某一生产要素处理不当,就会延长施工进度,在 此种情况下,施工单位就需要对生产要素进行管理,保证资 源种类、数量合理,提高土建工程施工进度管理效率。

\section{4 结束语}

总而言之, 做好进度管理工作是土建工程管理的重点, 对土建工程行业的快速发展起到重要作用。因此,建筑企业 就需要根据土建工程的具体特点, 对每一施工环节所需要 花费的时间准确制定,做好工程整体的进度规划,并对土建 工程施工中所需要使用的设备、施工材料、资金都充分管 理,进而保证土建工程可以在规定的时间内完成,提高建筑 企业在市场上的核心竞争力, 推动建筑企业实现可持续发 展。

\section{参考文献:}

[1]褚建勇,李宝顺.土建工程项目的施工进度管理与控 制综述 [J]. 城市建设理论研究 (电子版), 2014, (19): 597-597.

[2]王家幸.土建工程项目的施工进度管理与控制综述 [J].房地产导刊,2014,(17):457-457.

[3]刘杰,王亮.土建工程项目的施工进度管理与控制综 述[J].城市建设理论研究 (电子版),2014,(18):701-701.

[4]钟登华,间玉亮,张隽等.耦合改进 PERT 和 BBNs 的堆 石坝施工进度风险分析[J].水利学报,2017,48(1):52-60.

[5]钟登华,关涛,任炳昱等.基于改进重抽样法的高拱坝 施工进度仿真研究[J].水利学报,2016,47(4):473-482.

[6] 蒋宇一, 郡志清, 蔡宁等. 用于施工进度优化的 VNS-CRO 混合算法[J].江苏大学学报 (自然科学版),2016,37 (1):115-120,124.

[7]Deng-hua ZHONG,Wei HU,Bin-ping WU,Zheng LI,Jun ZHANG. 基于实时监控的面板堆石坝施工进度 - 成本 - 质 量动态均衡[J]. 浙江大学学报 (英文版) ( $\mathrm{A}$ 辑: 应用物理和 工程),2017,18(1):1-19. 